\title{
The history of mesowear: A review
}

\author{
Nicole L Ackermans ${ }^{\text {Corresp. } 1}$ \\ ${ }^{1}$ Clinic for Zoo Animals, Exotic Pets and Wildlife, Vetsuisse Faculty, University of Zurich, Zurich, Switzerland \\ Corresponding Author: Nicole L Ackermans \\ Email address: nicole.ackermans@uzh.ch
}

Published mesowear data was reviewed from the year 2000 to November 2019 (211 publications, 707 species, 1396 data points). Mesowear is a widely applied tooth wear technique that can be used to infer a herbivore's diet by scoring the height and sharpness of molar tooth cusps with the naked eye. Established as a fast and efficient tool for paleodiet reconstruction, the technique has seen multiple adaptations, simplifications, and extensions since its establishment, which have become complex to follow. The present study reviews all successive changes and adaptations to the mesowear technique in detail, providing a template for the application of each technique to the research question at hand. In addition, the array of species to which mesowear has been applied, along with the equivalent recorded diets have been compiled here in a large dataset. This review provides an insight into the metrics related to mesowear publication since its establishment. The large dataset overviews whether the species to which the various techniques of mesowear are applied are extant or extinct, their phylogenetic classification, their assigned diets and diet stability between studies, as a resource for future research on the topic. 
1 The history of mesowear: A review

Nicole L. Ackermans ${ }^{a}$

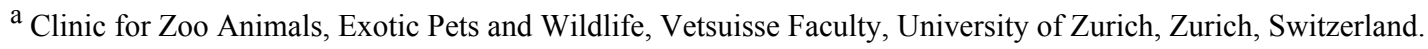
nlackermans@gmail.com

\section{ABSTRACT}

Published mesowear data was reviewed from the year 2000 to November 2019 (211 publications, 707 species, 1396 data points). Mesowear is a widely applied tooth wear technique that can be used to infer a herbivore's diet by scoring the height and sharpness of molar tooth cusps with the naked eye. Established as a fast and efficient tool for paleodiet reconstruction, the technique has seen multiple adaptations, simplifications, and extensions since its establishment, which have become complex to follow.

The present study reviews all successive changes and adaptations to the mesowear technique in

17 detail, providing a template for the application of each technique to the research question at hand. In addition, the array of species to which mesowear has been applied, along with the equivalent recorded diets have been compiled here in a large dataset. This review provides an insight into the metrics related to mesowear publication since its establishment. The large dataset overviews whether the species to which the various techniques of mesowear are applied are extant or extinct, their phylogenetic classification, their assigned diets and diet stability between studies, as a resource for future research on the topic.

\section{KEY WORDS}

tooth wear, diet reconstruction, herbivore, dietary proxy, palaeodiet 


\section{INTRODUCTION}

29 Tooth wear can be measured on different physiological scales, from the microscopic (2D

30 microwear (Walker et al., 1978) and 3D dental microwear texture analysis (Schulz et al., 2013a;

31 Calandra and Merceron, 2016; DeSantis, 2016; Green and Croft, 2018)) to the macroscopic

32 (mesowear, absolute wear (Fortelius and Solounias, 2000; Ackermans et al., 2019)), informing us

33 about a specimens', and by definition, a species' diet. Within tooth wear, attrition to the tooth's

34 enamel surface caused by tooth-on tooth contact is generally the main cause of wear in animals

35 with a browsing diet. The soft nature of a browse-based diet causes opposing teeth to wear

36 themselves, as the diet itself does not provide resistance (Sanson, 2006). Abrasion on the other

37 hand, is caused by internal or external abrasives, which wear tooth material upon contact (Janis,

38 2008). Grasses contain large amounts of internal opaline silicates that wear tooth enamel when

39 chewed repetitively (Baker et al., 1959), and, grazing animals generally tend to feed close to the

40 ground in open habitats, where plants become covered in external abrasives, e.g. dust and grit

41 (Janis and Fortelius, 1988). It is still debated whether tooth wear is mainly caused by phytoliths

42 (Xia et al., 2015; Merceron et al., 2016) or external abrasives (Healy, 1967; Sanson et al., 2007;

43 Damuth and Janis, 2011; Hummel et al., 2011; Lucas et al., 2013), and which is the main driver in

44 the evolution of hypsodonty, though the general agreement is that both types of abrasives

45 contribute at least somewhat to tooth wear and thus to the evolution of hypsodonty (Williams and 46 Kay, 2001; Kaiser et al., 2013).

47 Historically, tooth wear patterns have also been of interest for age determination, using the 48 visual aspect of the tooth's surface (Grant, 1982), using a technique that has been called 49 "macrowear" (Pinto-Llona, 2013), and confusingly, "mesowear" (Gonzalez-Socoloske et al., 50 2018). It is important to note that, while this "macrowear" is a species-specific technique - 
51 applicable to a variety of species from bears (Stiner, 1998) to manatees (Gonzalez-Socoloske et

52 al., 2018) - this technique is solely applied to estimate age based on wear, and does not provide

53 information on diet.

54 In the current review, mesowear is referred to as a series of techniques using a semi55 quantitative method to evaluate tooth wear visible on the tooth profile with the naked eye, or 56 handheld magnification. The original mesowear technique, or "mesowear I", was introduced by 57 Fortelius and Solounias (2000) (Table 1), as a method to reconstruct general paleodiets of fossil 58 ungulates by observing the macroscopic wear on their molars, specifically the M2. As such, in 59 terms of dietary signal duration, mesowear serves as a midway point between the unworn shape of a tooth representing a general diet at an evolutionary scale (i.e. herbivore or carnivore), and

61

62

63

microscopic wear, representing a specimen's last few meals (Grine, 1986). An abrasion-attrition wear gradient is used to assign dietary categories to herbivores, with browsers generally showing a more attrition-based wear pattern, and grazers a more abrasion-dominated pattern (Fortelius and Solounias, 2000). At the establishment of the technique, selenodont- (i.e. cow) or trilophodonttype (i.e. mastodon) molars were the target teeth for mesowear, applied by observing "the buccal edges of the paracones and metacones of upper molars" (Fortelius and Solounias, 2000, p. 3) with the naked eye or at low magnification (Fortelius and Solounias, 2000: Figure 1). As a direct consequence, mesowear is a fast, inexpensive technique for diet determination. Molar cusp relief or occlusal relief (OR) are defined in the original publication as "the relative distance between cusp height and inter-cusp valleys" (Fortelius and Solounias, 2000, p. 3), with low OR related to the high abrasion typical of the grazer diet. Cusp shape (CS) is therein defined by "the apex of the cusp being described as sharp, rounded or blunt" (Fortelius and Solounias, 2000, p. 3), using the maxillary M2 as the tooth of reference. Applying these variables allows dietary reconstruction 
74 based on the percentage of sharp, round, or blunt cusps; alongside the percentage of high relief.

75 Mesowear I was developed using a database of 64 extant species (Supplementary data), and was 76 succinctly applied to six fossil species of known diet to test its strength, followed by a blind test 77 on 20 specimens of Hippotherium (Kaiser et al., 2000) (Table1; Supplementary data). scored on a wide variety of taxa, noting that the choice of cusp was not critical. This hypothesis has been confirmed by Ackermans et al. (2018) in a feeding experiment on goats, though significant inter-cusp differences have been detected in rhinoceroses (Taylor et al. 2013) and certain equids (Taylor et al., 2016). Fortelius and Solounias (2000) also note the importance of scoring at least 10- and ideally 20-30 specimens per species and/or locality for a reasonable approximation of the score, though on palaeontological specimens, tentative dietary assumptions can be made using a single tooth (MacFadden, 2009; Rivals et al., 2017), as well-preserved specimens are rare. Although the initial assumption was that mesowear remains relatively stable throughout an individual's life (when very young or very old specimens are excluded), Rivals et al. (2007) later established the idea that mesowear varies based on initial crown height and can be different throughout an animal's lifetime. The age structure of samples measured by mesowear should thus be taken into consideration, especially in the case of brachydont species.

92 Table 1), expanding it to more teeth (Franz-Odendaal and Kaiser, 2003; Kaiser and Fortelius, 93 2003), and adapting the method to specific taxa (Fraser and Theodor, 2010; Purnell and Jones, 94 2012; Taylor et al., 2013; Butler et al., 2014; Saarinen et al., 2015; Ulbricht et al., 2015; 95 Kropacheva et al., 2017; Saarinen and Karme, 2017). Some, deeming OR a redundant measure not 96 fully independent from CS, simplified mesowear by only using categories of CS (Mihlbachler and 
97 Solounias, 2006; Widga, 2006), while others simplified the technique by combining OR and CS

98 into a single score (Rivals and Semprebon, 2006; Croft and Weinstein, 2008; Kaiser, 2009).

99 However, combining these scores can lead to oversimplification and, depending on the aim of the

100 study, the possibility to isolate tooth height or sharpness could be crucial. These simplified

101 versions of the original mesowear technique were deemed "mesowear II" by Solounias et al.

102 (2014). Further simplifications include a "mesowear ruler" system (Mihlbachler et al., 2011), and

103 a "mesowear angle" system (Saarinen et al., 2015). Mesowear I and II also have an extended

104 version, where intermediate stages were added to the original mesowear categories and a more

105 complex combined score was created to provide more detail (Winkler and Kaiser, 2011) (Table

106 1). "Mesowear III" or "inner-mesowear" was implemented by Solounias et al. (2014), where

107 scoring the inner enamel band of the tooth aimed to record a more precise signal, and represent a

108 shorter timeframe. Mesowear III has been applied in six other studies since it was established

109 (Supplementary data), but has been tested experimentally once, and results did not show more

110 precision than traditional mesowear when both techniques were applied to the same dataset

111 (Stauffer et al., 2019).

112 Traditionally, mesowear has either been scored directly on the specimens' teeth, on resin

113 casts, or on photographs of the specimen's teeth (Fortelius and Solounias, 2000). More recent

114 studies, however, have used 3D models of wear facets (Hernesniemi et al., 2011), or scored

115 mesowear directly onto 3D reconstructions from CT scanned skulls of live animals (Ackermans et

116 al., 2018). Various microscopy techniques have also been used as a means of scoring mesowear

117 on smaller specimens such as conodonts (Purnell and Jones, 2012), lagomorphs, and rodents

118 (Ulbricht et al., 2015; Kropacheva et al., 2017). 
121 the interpretation of corresponding results (Díaz-Sibaja et al., 2018). The aim of this review was

122 to therefore create a body of reference with precise definitions and short explanations for each

123 variation of the mesowear technique, to facilitate future applications. An overview of current

124 dental wear techniques exists (Green and Croft, 2018), but the current study provides a more 125 detailed and widely understandable overview of the history and progression of the mesowear 126 technique in particular. For this purpose, Table 1 lists all major amendments to the original 127 mesowear technique - including the various versions of mesowear I, II and III - along with a short

128 description and the scoring system used, thus hoping to ease comprehension of the available 129 techniques and promote comparability of studies.. In addition, a dataset was created reuniting the 130 dietary classifications of all species to which the mesowear technique has been applied thus far, 131 including specimen type, phylogenetic classification, and diet, as a readily accessible resource for 132 future research (Supplementary data).

\section{METHODS}

135 Publications were recorded using the search term "mesowear" in Google Scholar $(\mathrm{n}=1150)$, 136 PubMed $(n=25)$, ResearchGate $(n=230)$, and Web of Science $(n=142)$, for every year from 2000 137 until the present (11 November 2019). After removing duplicates and non-relevant studies (using 138 the terms "mesowear" or "macrowear" to describe wear on the macroscopic scale, without 139 referring to the Fortelius and Solounias (2000) mesowear technique), $n=211$ publications were 140 analysed. Book chapters, $\mathrm{PhD}, \mathrm{MSc}$ theses, and conference proceedings were included if they 141 contained otherwise unpublished original mesowear data. 
143 (references for the supplementary data are in Annex 1). A "various" diet indicates a diet change

144 for the same species within the publication (different localities or time periods). A species without

145 an assigned diet represents the lack of a diet indication or mesowear score within the text. An

146 "experimental" diet represents studies in which experimental diets were fed to animals in

147 controlled environments. When a study measured both mesowear and microwear (or another

148 dietary proxy) and the indicated diets diverged, the diet determined by mesowear scoring was

149 reported here. If species were listed with multiple entries for different localities, collections, or 150 subspecies within a single study, an average was made. If within a study mesowear was scored but

151 the diet was not defined, a diet was assigned according to the mesowear score reported in the

152 publication and previous research regarding the respective technique. Extant and extinct specimens

153 were classified as either "wild", "captive" (zoo, or experimental specimens), archaeological

154 (excavated in an archaeological context as defined by the original publication, designated 155 "extant_a" in the supplementary data) or fossil (fossil specimens of extant species designated 156 "extant_f" in the supplementary data). When a palaeontological specimen's identification could 157 not be established to the species level, the specimen was designated as "fossil" in the 158 supplementary data. For simplicity of analysis, mesowear techniques are designated mesowear I, 159 II, III, or a combination thereof in the supplementary data. Extended or simplified versions are 160 only noted in the case of the "mesowear ruler", "mesowear angle", "mesowear I and II - extended", 161 and all taxon-specific techniques. Data was arranged using pivot tables in Microsoft Excel (version 162 16.26) for graphic representation and interpretation.

Although mesowear can vary within species at different localities or different points in 164 time, the constancy of diets assigned to a species using mesowear was assessed using the dataset 
165 166 177 1).

178

\section{RESULTS}

180 The data collected (Supplementary data) shows that, when ordering the data by publication, 55\% assembled in the present study. It should be noted that the extreme variability between publications makes this a very coarse measure, however, it may either serve as an indication of the consistency of a species' diet, or as an indication of the difficulty to consistently assign a score to the species. When species were scored in more than one publication, a simple metric was devised: within a species, the diet recorded by the highest number of publications was calculated as a percentage of the total number of publications measuring mesowear in this species (i.e. For moose, Alces alces, mesowear was scored in seven publications, of which six reported a browser diet. Thus, using this metric, the moose's main-diet percentage is $86 \%$ browser). This percentage was then plotted against the number of publications scoring the species - in this case a higher main-diet percentage, alongside a high publication count indicated a more robust diet. This was measured using the dataset from the supplementary data including all types of diets, as well as using a simplified version of this dataset excluding all but the "grazer", "browser", and "mixed-feeder" diets (Fig.

181 of all publications score exclusively extinct specimens, while $17 \%$ apply mesowear to solely extant

182 species. Five percent of publications score solely extant archaeological or fossil specimens 183 (extant_a or extant_f); while 10\% score a mix of extinct and extant specimens, the rest scoring 184 combinations of the above (Fig. 2a). Only four publications applied mesowear to captive or 185 experimental animals representing roughly $2 \%$ of all studies. With regards to diet, the mixed diet 186 is most highly represented among all species (33\%) as it covers a large spectrum, followed by the 187 browser diet, at 26\% (Fig. 2b). 
When ordering the data by technique and publication, "mesowear I" on its own was scored

189

190

191

192

193

194

195

196

197

198

199

200

201

202

203

204

205

206

207

208

209

210

in $37 \%$ of studies, followed by "mesowear II" (21\%), "mesowear ruler" (14\%), and "mesowear I and II" (9\%), the rest using a combination thereof, or taxon-specific techniques (Fig. 2c). Most taxon-specific techniques were only used once in their original publication, with the exception of "mesowear adapted for Proboscidea", used in nine publications and "mesowear adapted for Conodonta" used in four. This fits within a statement from the original mesowear study, stating that "care should be taken not to lose the generality of the method, since restricting it to a single, morphologically uniform group will serve to limit the choice of recent species available for comparison" (Fortelius and Solounias, 2000, p. 10).

Out of the 211 publications analysed, 17 studies scored over 20 species, with the highest number of species being 85 (Solounias et al., 2013). Placental mammals were overwhelmingly scored (95\%), though they were surprisingly not the only class of animals to which mesowear was applied. Butler et al. (2014) adapted mesowear to marsupials, and Purnell and Jones (2012) applied mesowear to fossil conodonts (Table 1), a technique which was also applied to elasmobranches (McLennan, 2018). When sorted by order, artiodactyls were most represented (63\%), followed by perissodactyls (26\%) (Fig. 2d). Overall, out of 707 species (excluding “sp.”), Equus was by far the most scored genus, with 109 counts, followed by Tragelaphus with 38 counts, and Cervus at 37 counts. At the species level, Cervus elaphus was most commonly scored, with 19 counts, followed by Equus ferus (18 counts). In total, 177 species were scored in more than one publication, meaning that about $75 \%$ of species were only scored once (Supplementary data).

In part because of the number of times it is represented in the dataset and because of its extreme hypsodonty, the species with the most robust unchanging diet is Equus ferus, with 95\% diet robustness within 20 publications (Fig. 3). 


\section{DISCUSSION}

213 Although one may envision more sophisticated or precise methods of palaeodietary reconstruction,

214 it is important to remember that the original goal of the mesowear technique was to provide a fast

215 and cost-effective way of determining diets for a large number of species. It has been thoroughly 216 tested for this purpose and is extremely efficient in determining herbivore diets in a broad sense.

217 The array of mesowear measurement techniques stemming from the original method have their

218 respective pros and cons. If the technique is too simplified, we run the risk of hiding more subtle

219 variations in diet. The "mesowear ruler technique" was originally designed for use on horses

220 (Mihlbachler et al., 2011) but was later applied to other species without adaptation or further tests

221 of robustness (e.g. López-García et al., 2012; Rivals, 2012). Additionally, adapting the technique

222 to species with very specific tooth morphology, such as proboscideans (Saarinen et al., 2015), adds

223 the advantage of being able to score diets for these species, but this can only be reliably reached

224 through copious amounts of testing. Fine-tuning mesowear to every taxon runs the risk of

225 tarnishing the main goal of mesowear, that is being fast and cost efficient, and most importantly,

226 the creation of so many techniques reduces comparability between studies. Ideally, if the majority

227 of studies applied the extended version of mesowear (Winkler and Kaiser, 2011), from which

228 mesowear I scores can be easily deduced, this would enable higher comparability between studies,

229 all while remaining a quick and easy technique. Based on the present review, it is suggested to

230 apply only the extended mesowear technique in future studies. It can be measured as fast as any

231 other technique using a simple guide (Taylor et al., 2016: Figure 1), and extended mesowear I

232 scores are easily converted into either the conservative mesowear I scores, or extended and 233 conservative mesowear II scores (Winkler and Kaiser, 2011: Table 3). Thus, this technique allows 
234 flexibility as well as reproducibility between studies, providing a more cohesive body of work in 235 the future.

236 The "dietary robustness measure" established here may be coarse, but it provides a 237 different approach in investigating dietary robustness. It also represents the number of species 238 scored within a single publication, demonstrating some species have been scored in over ten 239 separate publications. Because there is no independent proxy for diet, this metric cannot 240 discriminate between stability of diet and reproducibility of the method itself, these are aspects 241 that are relevant to future development of the methodology, as some mesowear studies could 242 simply be interpreting the same mesowear data from a different perspective. However, providing 243 an overview of the variability in mesowear scoring may allow for a re-balance of mesowear 244 application in future studies, by increasing reproducibility and reducing repeated measures, e.g. on 245 species with high dietary robustness.

246 Since the creation of the mesowear technique, the number of publications per year, as well 247 as the type of publication (paleontological or not) has grown until around 2010, with a roughly 248 even distribution between non- and purely- palaeontological publications (Fig. 2a). The type of 249 mesowear technique applied over the years also varies, and the number of publications applying 250 solely "mesowear I" appears to decline over time as it becomes part of a combination of 251 techniques, while the use of taxon-specific techniques increases (Fig. 2b). Mesowear remains an 252 essential asset for dietary reconstruction and has become more frequently applied in combination 253 with other dietary proxies such as microwear or isotopic data, to provide a more accurate 254 representation of diet over different timescales, though these proxies are rarely in accordance, and 255 the development of wear on different scales remains to be investigated (Ackermans et al., in prep.256 b). 
A precise understanding of dietary timescales requires the establishment of a baseline, to

258 be used as a reference in defining the length of a dietary signal. In the case of mesowear, very few

259 publications investigate mesowear experimentally (Solounias et al., 2014; Kropacheva et al., 2017;

260 Ackermans et al., 2018; Stauffer et al., 2019) due to the cost and time required for long-term animal

261 experiments. Because of this, the duration of the dietary signal represented by mesowear remains

262 widely unknown. The few experimental tests of mesowear that can be considered long-term seem

263 to confirm this proxy as representing more of a general lifetime signal, at least in small ruminants

264 (Ackermans et al., 2018 on goats for 6 months; Ackermans et al., in prep.-a on sheep for 17

265 months). However, it is impossible to experimentally recreate the variations of nature, and the

266 comparison of the aforementioned results to those where mesowear shows more seasonal effects

267 (Kaiser and Schulz, 2006; Schulz et al., 2013b; Marom et al., 2018) requires further investigation.

268 Further areas of development for the mesowear technique could also explore objectivity through

269 automation using image processing algorithms or artificial intelligence (Karme, 2008), though

270 these methods are time-consuming to develop. A better understanding of the timescale represented

271 by mesowear can only improve the precision of dietary reconstructions, all while furthering our

272 understanding of the dental wear and dietary habits of extant species.

273

274

276

277

278

279

280

281

282

283

\section{ACKNOLEDGEMENTS}

I thank Marcus Clauss for input, ideas, and insightful corrections, as well the two reviewers, Florent Rivals and Ivan Calandra for their helpful and constructive comments.

\section{COMPETING INTERESTS}

The author declares no competing interests

\section{FUNDING}

This study was part of project 31003A_163300/1 funded by the Swiss National Science Foundation (Schweizerischer Nationalfonds zur Förderung der Wissenschaftlichen Forschung). 
284 Table 1: Additions and adaptations to the original mesowear technique - ordered by mesowear technique and date.

Figure 1. Dietary robustness of species represented in a mesowear dataset from 2000 to November 2019. Dietary robustness is a measure represented by the percentage of a species' main diet throughout publications, plotted against the number of publications featuring the species. Size of marker indicates the number of species per point (minimum 1, maximum 44). Markers are grey when multiple species occupy the same graph space (i.e. 41 species have the same diet when scored in two publications). Light green markers represent grazers, dark green markers represent browsers, and brown markers represent mixed diets, $n=188$ publications.

Figure 2. Overview of a mesowear dataset from 2000 to November 2019.

A: Specimen status of samples; B: Percentages of diets; C: Percentage of different mesowear techniques employed; D: Percentage of taxonomic orders. $n=211$ publications.

Figure 3. Yearly amount of publications scoring mesowear between 2000 and November 2019. 
303

304

305

306

307

308

309

310

311

312

313

314

315

316

317

318

319

320

321

322

323

324

325

326

327

328

329

330

331

332

333

334

335

336

337

338

339

340

341

342

343

344

345

346

\section{REFERENCES}

Ackermans, N. L., Clauss, M., Winkler, D. E., Schulz-Kornas, E., Kaiser, T. M., Müller, D. W. H., Kircher, P. R., Hummel, J. and Hatt, J.-M. (2019). Root growth compensates for molar wear in adult goats (Capra aegagrus hircus). Journal of Experimental Zoology Part A: Ecological and Integrative Physiology 331, 139-148.

Ackermans, N. L., Martin, L. F., Codron, D., Hummel, J., Kircher, P. R., Richter, H., Clauss, M. and Hatt, J.-M. (in prep.-a). Mesowear resembles a lifetime signal in a long-term feeding experiment on sheep (Ovis aries). Palaeogeography, Palaeoclimatology, Palaeoecology.

Ackermans, N. L., Winkler, D. E., Kaiser, T. M., Clauss, M. and Hatt, J.-M. (in prep.-b). A long last supper: response of dental microwear texture in sheep (Ovis aries) fed various amounts and sizes of quartz abrasives for 16 months.

Ackermans, N. L., Winkler, D. E., Schulz-Kornas, E., Kaiser, T. M., Müller, D. W. H., Kircher, P. R., Hummel, J., Clauss, M. and Hatt, J.-M. (2018). Controlled feeding experiments with diets of different abrasiveness reveal slow development of mesowear signal in goats (Capra aegagrus hircus). Journal of Experimental Biology 221, jeb186411.

Baker, G., Jones, L. H. P. and Wardrop, I. D. (1959). Cause of wear in sheeps' teeth. Nature 184, 1583-1584.

Butler, K., Louys, J. and Travouillon, K. (2014). Extending dental mesowear analyses to Australian marsupials, with applications to six Plio-Pleistocene kangaroos from southeast Queensland. Palaeogeography, Palaeoclimatology, Palaeoecology 408, 11-25.

Calandra, I. and Merceron, G. (2016). Dental microwear texture analysis in mammalian ecology. Mammal Review 46, 215-228.

Croft, D. A. and Weinstein, D. (2008). The first application of the mesowear method to endemic South American ungulates (Notoungulata). Palaeogeography, Palaeoclimatology, Palaeoecology 269, 103-114.

Damuth, J. and Janis, C. M. (2011). On the relationship between hypsodonty and feeding ecology in ungulate mammals, and its utility in palaeoecology. Biological Reviews 86, 733-758.

DeSantis, L. R. (2016). Dental microwear textures: reconstructing diets of fossil mammals. Surface Topography: Metrology and Properties 4, 023002.

Díaz-Sibaja, R., Jiménez-Hidalgo, E., Ponce-Saavedra, J. and García-Zepeda, M. L. (2018). A combined mesowear analysis of Mexican Bison antiquus shows a generalist diet with geographical variation. Journal of Paleontology 92, 1130-1139.

Fortelius, M. and Solounias, N. (2000). Functional characterization of ungulate molars using the abrasion-attrition wear gradient: a new method for reconstructing paleodiets. American Museum Novitates 3301, 1-36.

Franz-Odendaal, T. A. and Kaiser, T. M. (2003). Differential mesowear in the maxillary and mandibular cheek dentition of some ruminants (Artiodactyla). Annales Zoologici Fennici 40, 395-410.

Fraser, D. and Theodor, J. M. (2010). The use of gross dental wear in dietary studies of extinct lagomorphs. Journal of Paleontology 84, 720-729.

Gonzalez-Socoloske, D., Panjaitan, E., Marmontel, M. and Domning, D. P. (2018).

Florida manatees have less functional teeth and higher levels of molar wear than other

Peer) reviewing PDF | (2019:11:43344:1:1:NEW 21 Dec 2019) 
347 manatee populations. In XXXVI Reunión Internacional para el Estudio de los Mamíferos Marinos. 348 Villahermosa, Tabasco, Mexico.

349

350

351

352

353

354

355

356

357

358

359

360

361

362

363

364

365

366

367

368

369

370

371

372

373

374

375

376

377

378

379

380

381

382

383

384

385

386

387

388
Grant, A. (1982). The use of tooth wear as a guide to the age of domestic ungulates. In Ageing and sexing animal bones from archaeological sites, vol. BAR British series (ed. B. Wilson), pp. 91-108. Oxford: British Archaeological Reports.

Green, J. L. and Croft, D. A. (2018). Using Dental Mesowear and Microwear for Dietary Inference: A Review of Current Techniques and Applications. In Methods in Paleoecology: Reconstructing Cenozoic Terrestrial Environments and Ecological Communities, eds. D. A. Croft D. F. Su and S. W. Simpson), pp. 53-73. Cham: Springer International Publishing.

Grine, F. E. (1986). Dental evidence for dietary differences in Australopithecus and Paranthropus: a quantitative analysis of permanent molar microwear. Journal of Human Evolution 15, 783-822.

Healy, W. B. (1967). Ingestion of soil by sheep. Proceedings of the New Zealand Society of Animal Production 27, 109-120.

Hernesniemi, E., Blomstedt, K. and Fortelius, M. (2011). Multi-view stereo threedimensional reconstruction of lower molars of Recent and Pleistocene rhinoceroses for mesowear analysis. Palaeontologia Electronica 14, 1-15.

Hummel, J., Findeisen, E., Südekum, K.-H., Ruf, I., Kaiser, T. M., Bucher, M., Clauss, M. and Codron, D. (2011). Another one bites the dust: faecal silica levels in large herbivores correlate with high-crowned teeth. Proceedings of the Royal Society B: Biological Sciences 278, 1742-1747.

Janis, C. (2008). An evolutionary history of browsing and grazing ungulates. In The Ecology of Browsing and Grazing, eds. I. J. Gordon and H. H. T. Prins), pp. 21-45: Springer.

Janis, C. M. and Fortelius, M. (1988). On the means whereby mammals achieve increased functional durability of their dentitions, with special reference to limiting factors. Biological Reviews 63, 197-230.

Kaiser, T. M. (2009). Anchitherium aurelianense (Equidae, Mammalia): a brachydont "dirty browser" in the community of herbivorous large mammals from Sandelzhausen (Miocene, Germany). Paläontologische Zeitschrift 83, 131.

Kaiser, T. M. and Fortelius, M. (2003). Differential mesowear in occluding upper and lower molars: opening mesowear analysis for lower molars and premolars in hypsodont horses. Journal of Morphology 258, 67-83.

Kaiser, T. M., Müller, D. W. H., Fortelius, M., Schulz, E., Codron, D. and Clauss, M. (2013). Hypsodonty and tooth facet development in relation to diet and habitat in herbivorous ungulates: implications for understanding tooth wear. Mammal Review 43, 34-46.

Kaiser, T. M. and Schulz, E. (2006). Tooth wear gradients in zebras as an environmental proxy-a pilot study. Mitteilungen aus dem Hamburgischen Zoologischen Museum und Institut 103, 187-210.

Kaiser, T. M., Solounias, N., Fortelius, M., Bernor, R. L. and Schrenk, F. (2000). Tooth mesowear analysis on Hippotherium primigenium from the Vallesian Dinotheriensande (Germany). Carolinea: Beiträge zur naturkundlichen Forschung in Südwestdeutschland 58, 103114. 
389

390

391

392

393

394

395

396

397

398

399

400

401

402

403

404

405

406

407

408

409

410

411

412

413

414

415

416

417

418

419

420

421

422

423

424

425

426

427

428

429

430

431

Karme, A. (2008). Diet analysis for bunodont omnivore groups Suina and Hominidae: extending, objectifying and quantifying mesowear with 3D and GIS. In Evolutionary Palaeontology group, vol. Masters: University of Helsinki.

Kropacheva, Y. E., Sibiryakov, P. A., Smirnov, N. G. and Zykov, S. V. (2017). Variants of tooth mesowear in Microtus voles as indicators of food hardness and abrasiveness. Russian Journal of Ecology 48, 73-80.

López-García, J. M., Blain, H.-A., Burjachs, F., Ballesteros, A., Allué, E., Cuevas-Ruiz, G. E., Rivals, F., Blasco, R., Morales, J. I. and Hidalgo, A. R. (2012). A multidisciplinary approach to reconstructing the chronology and environment of southwestern European Neanderthals: the contribution of Teixoneres cave (Moià, Barcelona, Spain). Quaternary Science Reviews 43, 3344.

Lucas, P. W., Casteren, A. v., Al-Fadhalah, K., Almusallam, A. S., Henry, A. G., Michael, S., Watzke, J., Reed, D. A., Diekwisch, T. G. H. and Strait, D. S. (2013). The role of dust, grit and phytoliths in tooth wear. Annales Zoolgici Fennici 51, 143-152.

MacFadden, B. J. (2009). Three-toed browsing horse Anchitherium (Equidae) from the Miocene of Panama. Journal of Paleontology 83, 489-492.

Marom, N., Garfinkel, Y. and Bar-Oz, G. (2018). Times in between: A zooarchaeological analysis of ritual in Neolithic Sha'ar Hagolan. Quaternary International 464, 216-225.

McLennan, L. (2018). Tooth Wear, Microwear and Diet in Elasmobranchs, vol. PhD. University of Leicester: Department of Geology.

Merceron, G., Ramdarshan, A., Blondel, C., Boisserie, J.-R., Brunetiere, N., Francisco, A., Gautier, D., Milhet, X., Novello, A. and Pret, D. (2016). Untangling the environmental from the dietary: dust does not matter. Proceedings of the Royal Society B: Biological Sciences 283, 20161032.

Mihlbachler, M. C., Rivals, F., Solounias, N. and Semprebon, G. M. (2011). Dietary change and evolution of horses in North America. Science 331, 1178-1181.

Mihlbachler, M. C. and Solounias, N. (2006). Coevolution of tooth crown height and diet in oreodonts (Merycoidodontidae, Artiodactyla) examined with phylogenetically independent contrasts. Journal of Mammalian Evolution 13, 11-36.

Pinto-Llona, A. C. (2013). Macrowear and occlusal microwear on teeth of cave bears Ursus spelaeus and brown bears Ursus arctos: Inferences concerning diet. Palaeogeography, Palaeoclimatology, Palaeoecology 370, 41-50.

Purnell, M. A. and Jones, D. (2012). Quantitative analysis of conodont tooth wear and damage as a test of ecological and functional hypotheses. Paleobiology 38, 605-626.

Rivals, F. (2012). Ungulate feeding ecology and middle Pleistocene paleoenvironments at Hundsheim and Deutsch-Altenburg 1 (eastern Austria). Palaeogeography, Palaeoclimatology, Palaeoecology 317, 27-31.

Rivals, F., Mihlbachler, M. C. and Solounias, N. (2007). Effect of ontogenetic-age distribution in fossil and modern samples on the interpretation of ungulate paleodiets using the mesowear method. Journal of Vertebrate Paleontology 27, 763-767.

Rivals, F. and Semprebon, G. M. (2006). A comparison of the dietary habits of a large sample of the Pleistocene pronghorn Stockoceros onusrosagris from the Papago Springs Cave in Arizona to the modern Antilocapra americana. Journal of Vertebrate Paleontology 26, 495-500. 
432

433

434

435

436

437

438

439

440

441

442

443

444

445

446

447

448

449

450

451

452

453

454

455

456

457

458

459

460

461

462

463

464

465

466

467

468

469

470

471

472

473

474

475

Rivals, F., Uzunidis, A., Sanz, M. and Daura, J. (2017). Faunal dietary response to the Heinrich Event 4 in southwestern Europe. Palaeogeography, Palaeoclimatology, Palaeoecology 473, 123-130.

Saarinen, J. and Karme, A. (2017). Tooth wear and diets of extant and fossil xenarthrans (Mammalia, Xenarthra) - Applying a new mesowear approach. Palaeogeography, Palaeoclimatology, Palaeoecology 476, 42-54.

Saarinen, J., Karme, A., Cerling, T., Uno, K., Säilä, L., Kasiki, S., Ngene, S., Obari, T., Mbua, E. and Manthi, F. K. (2015). A new tooth wear-based dietary analysis method for proboscidea (Mammalia). Journal of Vertebrate Paleontology 35, e918546.

Sanson, G. (2006). The biomechanics of browsing and grazing. American Journal of Botany 93, 1531-1545.

Sanson, G. D., Kerr, S. A. and Gross, K. A. (2007). Do silica phytoliths really wear mammalian teeth? Journal of Archaeological Science 34, 526-531.

Schulz, E., Calandra, I. and Kaiser, T. M. (2013a). Feeding ecology and chewing mechanics in hoofed mammals: 3D tribology of enamel wear. Wear 300, 169-179.

Schulz, E., Fraas, S., Kaiser, T. M., Cunningham, P. L., Ismail, K. and Wronski, T. (2013b). Food preferences and tooth wear in the sand gazelle (Gazella marica). Mammalian BiologyZeitschrift für Säugetierkunde 78, 55-62.

Solounias, N., Semprebon, G., Mihlbachler, M. and Rivals, F. (2013). Paleodietary comparisons of ungulates between the late Miocene of China, and Pikermi and Samos in Greece. In Fossil Mammals of Asia: Neogene Biostratigraphy and Chronology. , eds. X. Wang L. J. Flynn and M. Fortelius), pp. 676-692. New York: Columbia University Press.

Solounias, N., Tariq, M., Hou, S., Danowitz, M. and Harrison, M. (2014). A new method of tooth mesowear and a test of it on domestic goats. Annales Zoologici Fennici 51, 111-118.

Stauffer, J. B., Clauss, M., Müller, D. W. H., Hatt, J.-M. and Ackermans, N. L. (2019). Testing mesowear III on experimentally fed goats (Capra aegagrus hircus). Annales Zoologici Fennici 56, 85-91.

Stiner, M. C. (1998). Mortality analysis of Pleistocene bears and its paleoanthropological relevance. Journal of Human Evolution 34, 303-326.

Taylor, L. A., Kaiser, T. M., Schwitzer, C., Müller, D. W. H., Codron, D., Clauss, M. and Schulz, E. (2013). Detecting inter-cusp and inter-tooth wear patterns in Rhinocerotids. PLoS One 8, e80921.

Taylor, L. A., Müller, D. W. H., Schwitzer, C., Kaiser, T. M., Castell, J. C., Clauss, M. and Schulz-Kornas, E. (2016). Comparative analyses of tooth wear in free-ranging and captive wild equids. Equine Veterinary Journal 48, 240-245.

Ulbricht, A., Maul, L. C. and Schulz, E. (2015). Can mesowear analysis be applied to small mammals? A pilot-study on leporines and murines. Mammalian Biology-Zeitschrift für Säugetierkunde 80, 14-20.

Viranta, S. and Mannermaa, K. (2014). Mesowear analysis on Finnish medieval horses. Annales Zoologici Fennici 51, 119-123.

Walker, A., Hoeck, H. N. and Perez, L. (1978). Microwear of mammalian teeth as an indicator of diet. Science 201, 908-910.

Widga, C. (2006). Niche variability in late Holocene bison: a perspective from Big Bone Lick, KY. Journal of Archaeological Science 33, 1237-1255. 
476 Williams, S. H. and Kay, R. F. (2001). A comparative test of adaptive explanations for 477 hypsodonty in ungulates and rodents. Journal of Mammalian Evolution 8, 207-229.

478 Winkler, D. E. and Kaiser, T. M. (2011). A case study of seasonal, sexual and ontogenetic 479 divergence in the feeding behaviour of the moose (Alces alces, Linné, 1758). Verhandlungen des 480 Naturwissenschaftlichen Vereins Hamburg 46, 331-348.

481 Xia, J., Zheng, J., Huang, D., Tian, Z. R., Chen, L., Zhou, Z., Ungar, P. S. and Qian, L. 482 (2015). New model to explain tooth wear with implications for microwear formation and diet 483 reconstruction. Proceedings of the National Academy of Sciences 112, 10669-10672. 


\section{Table $\mathbf{1}$ (on next page)}

Table 1: Additions and adaptations to the original mesowear technique - ordered by mesowear technique and date. 
1 Table 1: Additions and adaptations to the original mesowear technique - ordered by mesowear technique and 2 date. 3

\begin{tabular}{|c|c|c|c|}
\hline Technique & Reference & Description & Scores \\
\hline $\begin{array}{l}\text { Original mesowear - } \\
\text { Mesowear I }\end{array}$ & $\begin{array}{l}\text { (Fortelius and Solounias, } \\
2000 \text { ) }\end{array}$ & $\begin{array}{l}\text {-Using the naked eye or } \mathrm{x} 10 \\
\text { magnification } \\
\text {-Scoring only sharpest buccal } \\
\text { cusp of maxillary M2 } \\
\text {-Last molar in occlusion and M1 } \\
\text { shape similar to M2 } \\
\text {-Percentage of high relief and } \\
\text { Percentage of sharp, round and } \\
\text { blunt cusps }\end{array}$ & $\begin{array}{l}\text { OR: low, high } \\
\text { CS: blunt, round, sharp }\end{array}$ \\
\hline $\begin{array}{l}\text { Mesowear I- } \\
\text { Adapted for Equidae }\end{array}$ & (Kaiser and Fortelius, 2003) & $\begin{array}{l}\text { Method extended to all apices on } \\
\text { maxillary P4-M3 in equids }\end{array}$ & Original mesowear \\
\hline Mesowear I & $\begin{array}{l}\text { (Franz-Odendaal and Kaiser, } \\
\text { 2003) }\end{array}$ & $\begin{array}{l}\text { Method extended to maxillary M3, } \\
\text { and mandibular M2 in ruminants }\end{array}$ & Original mesowear \\
\hline $\begin{array}{l}\text { Mesowear I- } \\
\text { Adapted for } \\
\text { Lagomorpha }\end{array}$ & (Fraser and Theodor, 2010) & $\begin{array}{l}\text { "Cusp relief" combined with } \\
\text { "buccal shearing crush wear" on } \\
\text { maxillary and mandibular P4-M2 - } \\
\text { resulting in } 5 \text { dietary classes }\end{array}$ & $\begin{array}{l}\text { 1: } 45^{\circ} \text { enamel-dentine relief with } \\
\text { no additional wear - highly } \\
\text { folivorous } \\
\text { 2: } 45^{\circ} \text { enamel- dentine relief with } \\
\text { buccal shearing crush wear - } \\
\text { leaves \& woody materials } \\
\text { 3: } 45^{\circ} \text { enamel-dentine relief with } \\
\text { buccal shearing crush \& phase II } \\
\text { wear - leaf, twig, \& fruit diet } \\
\text { 4: } 90^{\circ} \text { enamel-dentine relief with } \\
\text { no additional wear - open area } \\
\text { grazers } \\
5: 90^{\circ} \text { enamel-dentine relief with } \\
\text { buccal shearing crush wear - open } \\
\text { area browsers }\end{array}$ \\
\hline
\end{tabular}

\begin{tabular}{|c|c|c|c|}
\hline $\begin{array}{l}\text { Mesowear I - } \\
\text { Adapted for } \\
\text { Conodonta }\end{array}$ & (Purnell and Jones, 2012) & Scored on P1 elements & \\
\hline $\begin{array}{l}\text { Mesowear I - } \\
\text { Adapted for voles }\end{array}$ & (Kropacheva et al., 2017) & Maxillary M1-M2, mandibular m1 & $\begin{array}{l}\text { Occlusal relief } 1-7 \\
\text { Lateral facet development 1-3 }\end{array}$ \\
\hline $\begin{array}{l}\text { Mesowear II - } \\
\text { "Mesowear ruler" }\end{array}$ & (Mihlbachler et al., 2011) & $\begin{array}{l}\text { Simplified score using gauges and } \\
\text { a seven-point system }\end{array}$ & Combined score 0-6 \\
\hline $\begin{array}{l}\text { Mesowear II - } \\
\text { "Mesowear ruler" }\end{array}$ & (Wolf et al., 2012) & additional intermediate scores & $\begin{array}{l}\text { Combined score } 0-13 \\
\text { in increments of } 0.5\end{array}$ \\
\hline $\begin{array}{l}\text { "Mesowear angles" - } \\
\text { Adapted for } \\
\text { Proboscidea }\end{array}$ & (Saarinen et al., 2015) & $\begin{array}{l}\text { "Mean mesowear angles of three } \\
\text { central lamellae in occlusion" } \\
\text { on all except deciduous teeth }\end{array}$ & $\begin{array}{l}\text { Mean mesowear angle } \\
<106^{\circ} \text { : C3-plant based diet } \\
>130^{\circ} \text { : C4-plant based diet } \\
\text { (grazer) }\end{array}$ \\
\hline
\end{tabular}




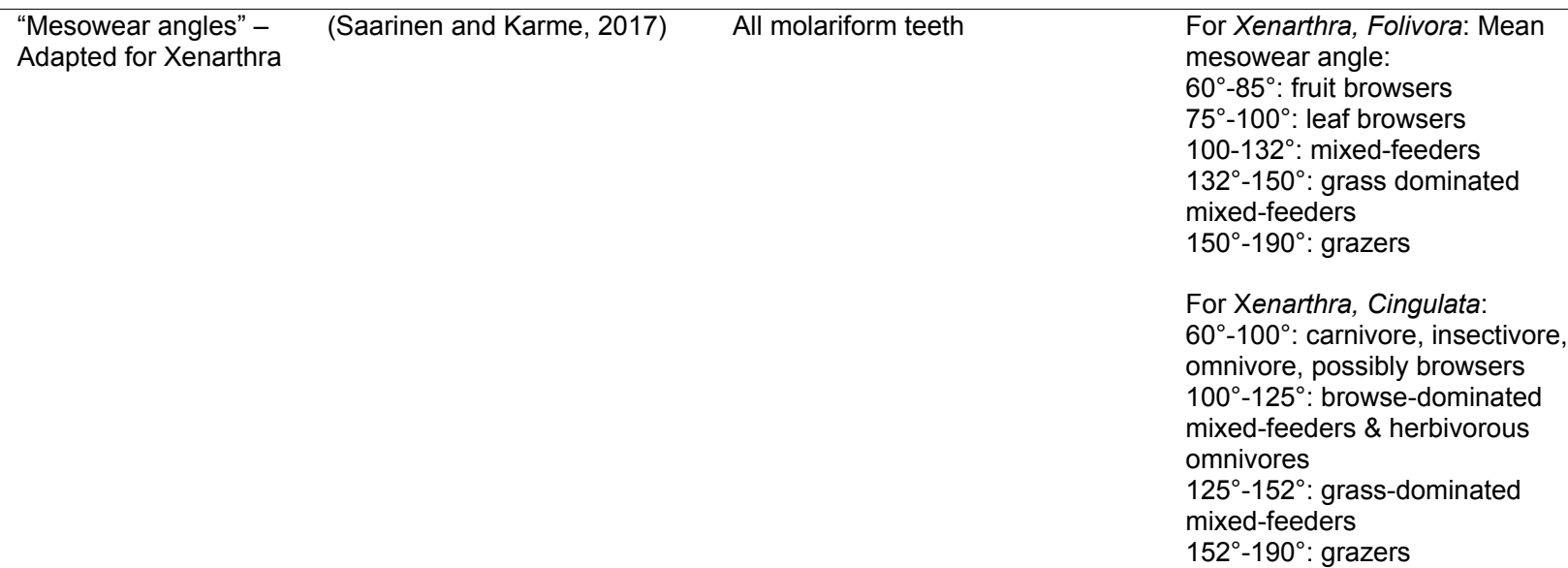

\begin{tabular}{|c|c|c|c|}
\hline Mesowear II & $\begin{array}{l}\text { (Mihlbachler and Solounias, } \\
2006 \text { ) }\end{array}$ & $\begin{array}{l}\text { Simplified score, only proportion of } \\
\text { sharp cusps }\end{array}$ & $\begin{array}{l}\text { Proportion of sharp cusps: } \\
\text { 40-100\%: Clean browser } \\
\text { 20-40\%: Mixed feeders: } \\
\text { 0-20\%: Grazer }\end{array}$ \\
\hline $\begin{array}{l}\text { Mesowear II } \\
\text { "quantitative } \\
\text { mesowear" }\end{array}$ & (Widga, 2006) & $\begin{array}{l}\text { Interval measurements of cusp } \\
\text { and saddle heights to calculate } \\
\text { cusp relief }\end{array}$ & $\begin{array}{l}\text { Index of cusp relief: } \\
\text { Low ICR: grazer } \\
\text { High ICR: browser }\end{array}$ \\
\hline Mesowear II & (Rivals and Semprebon, 2006) & $\begin{array}{l}\text { Simplified score combining OR } \\
\text { and CS }\end{array}$ & $\begin{array}{l}\text { 0: high relief } \& \text { sharp cusps } \\
\text { 1: high relief } \& \text { round cusps } \\
\text { 2: low relief } \& \text { round cusps } \\
\text { 3: low relief } \& \text { blunt cusps }\end{array}$ \\
\hline Mesowear II & (Kaiser, 2009) & & $\begin{array}{l}\text { 0: high relief } \& \text { sharp cusps } \\
\text { 1: high relief } \& \text { round cusps } \\
\text { 2: low relief } \& \text { sharp cusps } \\
\text { 3: low relief } \& \text { round cusps } \\
\text { 4: low relief \& blunt cusps }\end{array}$ \\
\hline Mesowear II & (Rivals et al., 2009) & & $\begin{array}{l}\text { 0: high relief \& sharp cusps } \\
\text { 1: high relief \& round cusps } \\
\text { 2: low relief \& round cusps } \\
\text { 2.5: low relief \& sharp cusps } \\
\text { 3: low relief \& blunt cusps }\end{array}$ \\
\hline Mesowear II & (Croft and Weinstein, 2008) & & $\begin{array}{l}0: \text { high relief } \& \text { sharp cusps } \\
\text { 1: high relief } \& \text { round cusps } \\
\text { 2: low relief \& round cusps } \\
\text { 2.5: low relief } \& \text { sharp cusps } \\
\text { 3: high/low relief \& blunt cusps }\end{array}$ \\
\hline Mesowear II & (Fraser et al., 2014) & $\begin{array}{l}\text { Method extended to mandibular } \\
\text { p4-m3 for ruminants }\end{array}$ & $\begin{array}{l}\text { 1: high relief \& sharp cusps } \\
\text { 2: high relief \& round cusps } \\
\text { 3: high relief \& very round cusps } \\
\text { 4: low relief \& round-blunt cusps } \\
\text { 5: low relief \& flat-blunt cusps }\end{array}$ \\
\hline $\begin{array}{l}\text { Mesowear II - } \\
\text { Adapted for } \\
\text { Marsupialia }\end{array}$ & (Butler et al., 2014) & $\begin{array}{l}\text { Use of classical mesowear and a } \\
\text { combined score on the maxillary } \\
\text { left maxillary molars, scoring } \\
\text { sharpest buccal cusp }\end{array}$ & $\begin{array}{l}\text { Combined score as in (Kaiser et } \\
\text { al., 2009) }\end{array}$ \\
\hline $\begin{array}{l}\text { Mesowear I \& II - } \\
\text { Expanded }\end{array}$ & (Winkler and Kaiser, 2011) & $\begin{array}{l}\text { Intermediate stages added to } \\
\text { original and combined score }\end{array}$ & $\begin{array}{l}\text { OR: low, high-low, high, high-high. } \\
\text { CS: blunt, round-round, round, } \\
\text { round-sharp, sharp. } \\
\text { Combined score } 1-17\end{array}$ \\
\hline $\begin{array}{l}\text { Mesowear I and II - } \\
\text { Expanded, }\end{array}$ & (Taylor et al., 2013) & $\begin{array}{l}\text { Expanded version and combined } \\
\text { score on maxillary P2-M2. }\end{array}$ & Combined score 1-11 \\
\hline
\end{tabular}




\begin{tabular}{llll}
\hline Mesowear III - & (Solounias et al., 2014) & Scores the second enamel band, & Enamel band wear states: \\
"Inner mesowear" & using a stereo-microscope. & 1: ideal browser \\
& Mesial side, distal side and & 2-3: intermediate \\
& junction point are scored & 4: ideal grazer \\
& separately. & Junction point score 1-4 \\
\hline
\end{tabular}

6 


\section{Figure 1}

Dietary robustness of species represented in a mesowear dataset from 2000 to November 2019.

Dietary robustness is a measure represented by the percentage of a species' main diet throughout publications, plotted against the number of publications featuring the species. Size of marker indicates the number of species per point (minimum 1, maximum 44). Markers are grey when multiple species occupy the same graph space (i.e. 41 species have the same diet when scored in two publications). Light green markers represent grazers, dark green markers represent browsers, and brown markers represent mixed diets, $n=188$ publications.

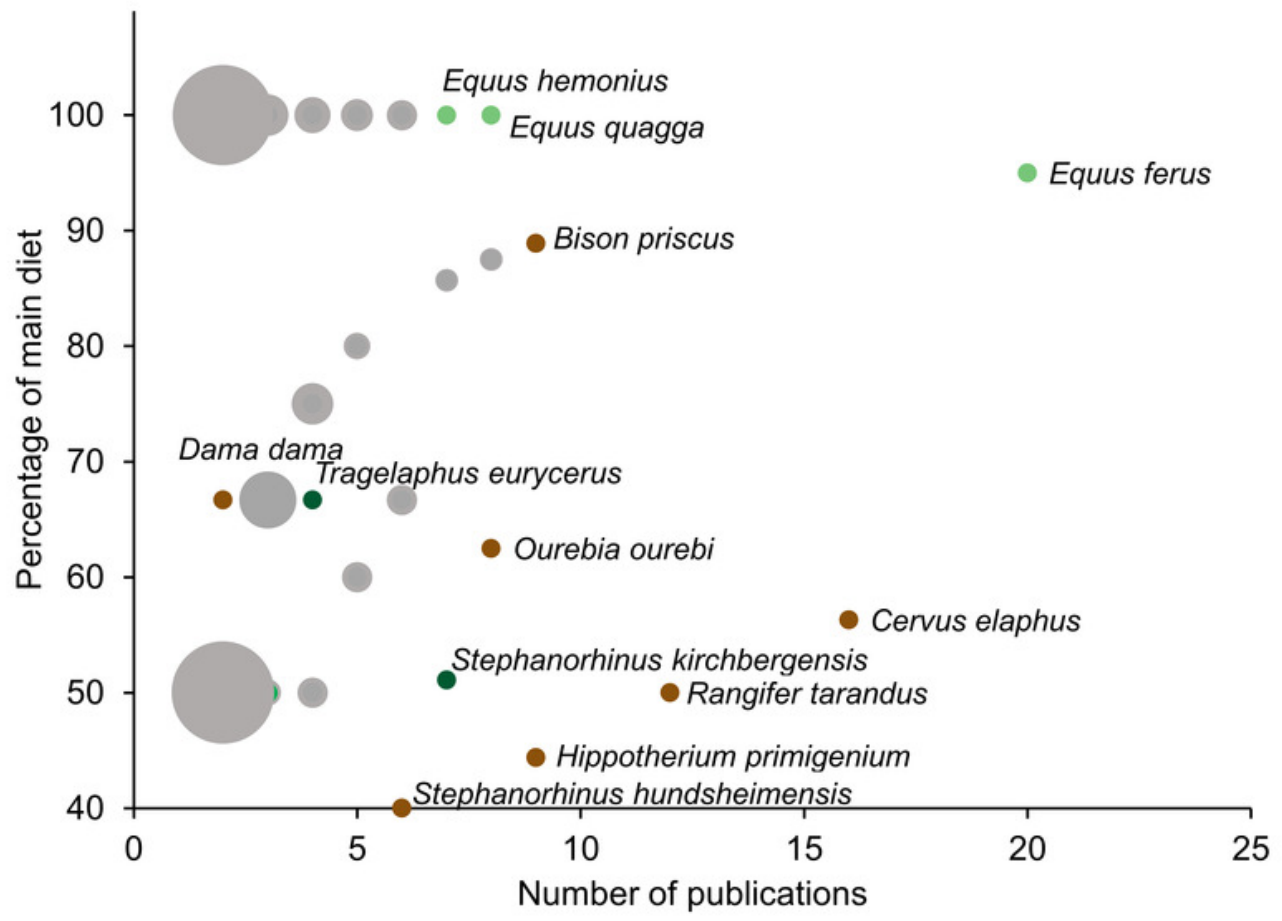




\section{Figure 2}

Overview of a mesowear dataset from 2000 to November 2019.

A: Specimen status of samples; B: Percentages of diets; C: Percentage of different mesowear techniques employed; D: Percentage of taxonomic orders. $n=211$ publications.

A

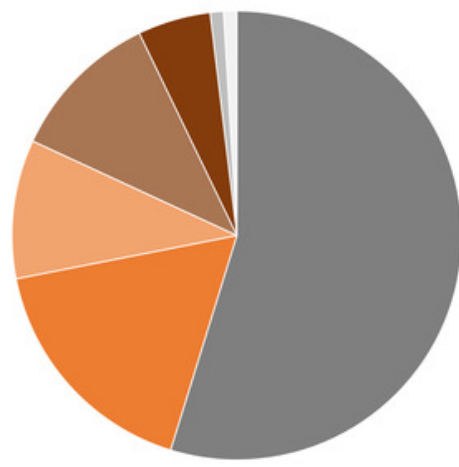

C

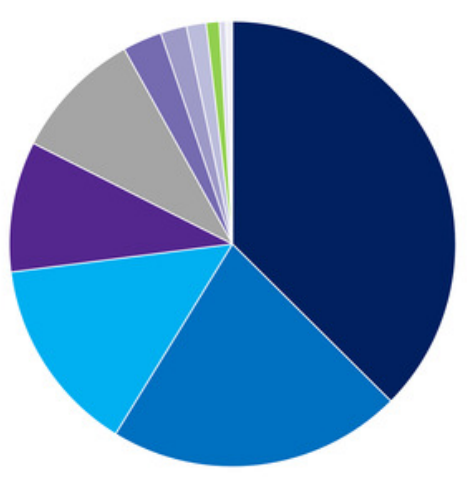

Specimen type

wextinct

m extant

= extinct \& extant

m extant fossil/archaeo. \& extinct

- extant fossil/archaeological

extant \& extant fossil/archaeo. \& extinct

extant \& extant fossil, archaeo.

Technique

- Mesowear I

- Mesowear II

" Mesowear ruler

- Mesowear I and II

"nspecific techniques

= Mesowear I and ruler

= Mesowear II and III

- Mesowear I and II -

extended

- Mesowear III
B

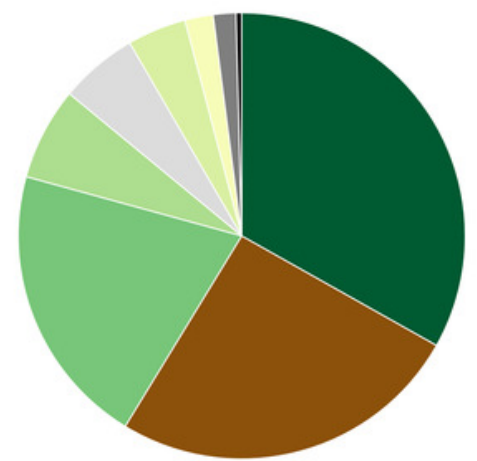

D

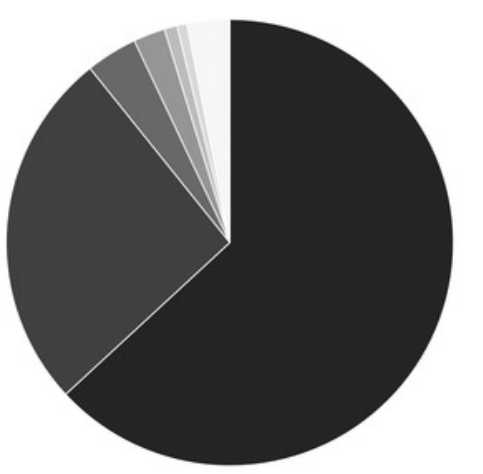

Diet

n Mixed

- Browser

= Grazer

= Grass-dominated mixed

= Varies

Browse-dominated mixed

Frugivore

n Other

- Experimental

Order

- Artiodactyla

- Perissodactyla

= Diprotodontia

E Proboscidea

= Cingulata

- Pilosa

Other 
Figure 3

Yearly amount of publications scoring mesowear between 2000 and November 2019.

A: Paleontological specimens versus non-paleontological specimens; B: Different techniques used to score mesowear, data sorted by number of publications. $n=211$ publications. *Not a complete year. 
A

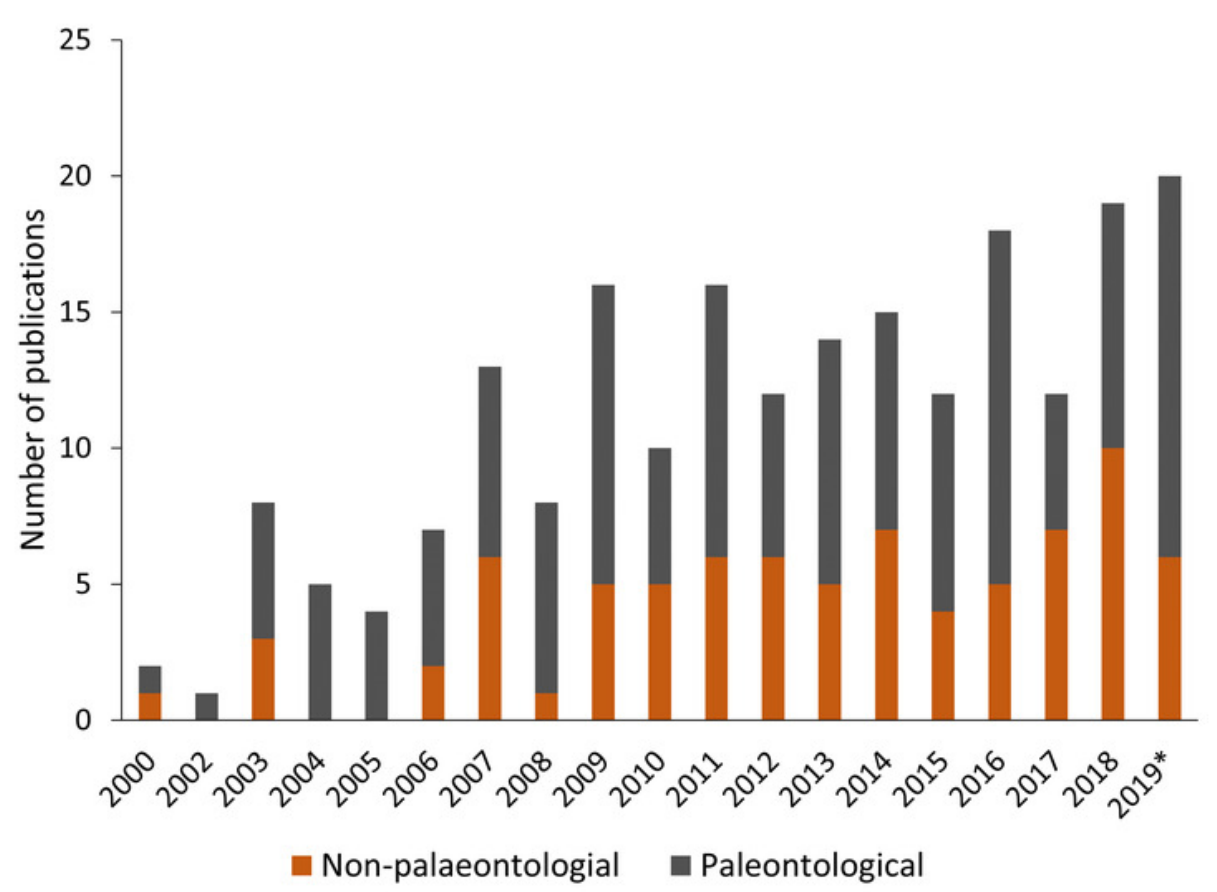

B

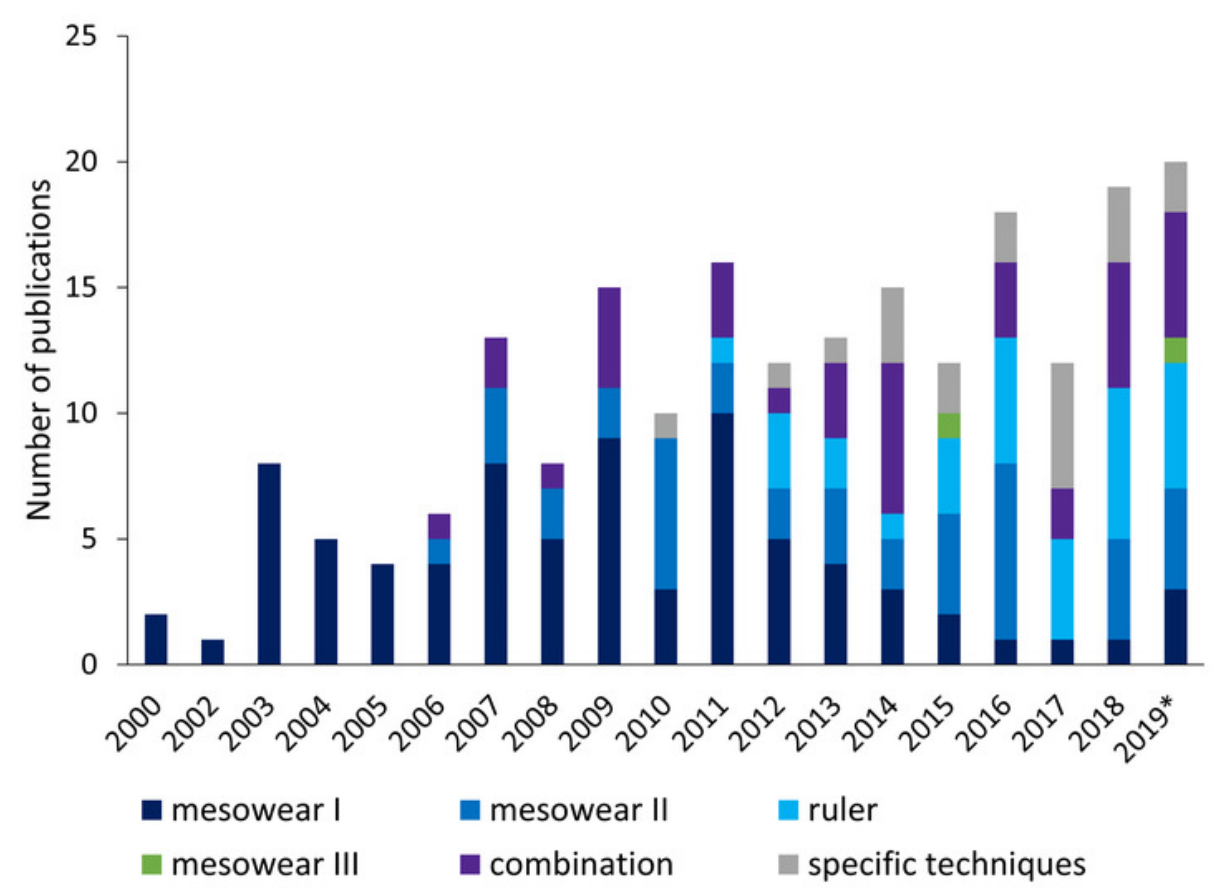

